\title{
Fundraising Strategies to Optimize Zakah Potential in Indonesia: An Exploratory Qualitative Study
}

\author{
Rahmatina A. Kasri ${ }^{1}$, Niken Iwani S. Putri ${ }^{2}$
}

\begin{abstract}
This paper aims to identify and evaluate fundraising strategies implemented by various types of zakah institutions in Indonesia. The study employs a qualitative research approach through semi-structured interviews with zakah organizations in Indonesia. The main finding suggests some differences in the fundraising strategies. Corporate and government zakah agencies tend to use traditional fundraising strategies, with a partnership approach for collecting zakah and a community-oriented approach for communicating zakah. In contrast, private zakah agencies tend to use market-oriented fundraising strategies allied with retail collection approach and an individual communication approach.
\end{abstract}

Keywords: fundraising strategy, zakah organizations, Islamic charities, Islamic voluntary sector.

\begin{abstract}
Abstrak. Artikel ini bertujuan untuk mengidentifikasi dan mengevaluasi strategi penggalangan dana yang dilakukan oleh berbagai jenis lembaga zakat di Indonesia. Studi ini menggunakan pendekatan penelitian kualitatif dengan wawancara semi-terstruktur dengan lembaga zakat di Indonesia. Temuan utama penelitian ini menunjukkan terdapatnya perbedaan dalam strategi penggalangan dana tersebut. Lembaga zakat perusahaan dan pemerintah cenderung menggunakan strategi penggalangan dana tradisional, dengan pendekatan kemitraan untuk mengumpulkan zakat dan pendekatan yang berorientasi pada masyarakat untuk mengkomunikasikan zakat. Sebaliknya, lembaga zakat swasta cenderung menggunakan strategi penggalangan dana yang berorientasi pasar dengan pendekatan pengumpulan ritel dan pendekatan komunikasi individual.
\end{abstract}

Kata kunci: strategi penggalangan dana, organisasi zakat, lembaga amal Islam, sektor sukarela Islam.

\section{How to Cite:}

Kasri, R.A., \& N.I.S. Putri. (2018). Fundraising Strategies to Optimize Zakah Potential in Indonesian: An Exploratory Qualitative Study. Al-Iqtishad: Jurnal Ilmu Ekonomi Syariah (Journal of Islamic Economics). Vol. 10 (1): 1 - 24. doi: http//dx.doi.org/10.15408/aiq.v10i1.6191 
Al-Iqtishad: Jurnal Ilmu Ekonomi Syariah (Journal of Islamic Economics) Vol. 10 (1), January 2018

\section{Introduction}

Importance of zakah institution in Islamic society is unquestionable. Zakah not only serves as the third pillar of Islam, but also regarded as an institution and a system which ensures the equitable distribution of income. This is possible because zakah is the predetermined share of wealth to be distributed among the deserving categories prescribed by God (Al-Qardawi, 2000). It is also an obligation for the wealthy Muslim and primarily aimed to help the poor (Ahmed, 2004). In theory, therefore, to achieve these laudable objectives the amount of zakah collected should be very large.

Despite this, the amount of zakah collected in various Muslim societies has been relatively low. Kahf (1999) estimated that the ratio of zakah revenue to national income (gross domestic product, or GDP) in three countries adopting the obligatory zakah system - Saudi Arabia, Yemen, and Pakistan - was only between 0.3 and 0.4 percent of GDP. In the case of Indonesia, he estimated that the potential for zakah was around 1 to 2 percent of the country's GDP. In the context of Indonesia, a recent study, which also included the potential for zakah from industries and financial sectors, estimated that the potential amount could reach Rp 217 trillion, or around 3.4 percent of Indonesia’s GDP (Firdaus et al., 2012). However, in practice, zakah collection in the country was only $\mathrm{Rp} 740$ billion in 2007 , increasing to $\mathrm{Rp}$ 3.65 trillion by 2015 (BAZNAS, 2016). These figures collected from all the types of zakah organizations in Indonesia, i.e., government, corporate and private zakah organizations, and are far below the estimations mentioned above.

This low level of zakah collection believed to be associated with the limited collection methods and ineffective collection/fundraising strategies implemented by zakah institutions in most Muslim countries (see, among others, Othman 1990; Faridi 1993; Abdu 2009), including Indonesia (Widarwati, Afif \& Zazim, 2017). Furthermore, quite recently Wibisono (2015) noted that non-governmental zakah organizations have consistently achieved more significant levels of collection of zakah in Indonesia. Thus there is an indication that the type of zakah organization also affects the effectiveness of zakah collection in the country.

With this perspective in mind, the main purpose of this paper is to identify and assess differences in the fundraising strategies implemented by different types of zakah institutions (i.e., government, corporate and private zakah organizations) in Indonesia in increasing effectiveness and optimizing zakah fundraising in the country. To achieve the objectives, it employs a qualitative research approach through semi-structured interviews with the six most significant zakah organizations in Indonesia. The results are subsequently analyzed using thematic analysis.

Following this introduction, the structure of this paper is as follows. Section two reviews several theoretical aspects related to fundraising as implemented by 
various types of organizations, including zakah organizations. Section three explains the data and methods utilized in the study, while section four presents and analyzes the empirical findings. The final section concludes the study.

\section{Literature Review}

\section{Concepts of Zakah and Zakah Administration}

Literally, zakah means 'growth', 'increase', or 'purity' of wealth. When the context is a person, it means 'to improve' or 'to make better'. It is also interpreted as 'blessing', 'growth', 'cleanliness', 'praise' and 'betterment' (Al-Qardawi, 2000). Furthermore, according to the Fiqh Encyclopaedia, zakah can be understood as a due on specific items of assets/properties, in specific percentages, on a yearly basis, and in satisfaction of certain conditions or nisab (in Ahmed, 2004).

In terms of zakah administration, the majority of commentators agree that Islamic state institutions have the ultimate right to collect and distribute zakah in a Muslim country (Ahmed, 2004; Al-Qardawi, 2000; Pramanik, 1993). However, in the current context, it is notable that such states - i.e. those with governments that take Islam as their ideology, Islamic laws as the foundation of their constitutions, and Islamic standards as the basis for their social, economic and political structures - rarely exist. Thus, Muslim scholars argue that zakah does not have to be fully managed by governments (Al-Qardawi, 2000). Moreover, even if a Muslim state collects and distributes zakah, it is contended that zakah payers (muzakki) could partially pay and distribute zakah independently, in order to fully benefit society and as practised in historical times by Caliph Uthman bin Affan (Al-Qardawi, 2000). Civil societies and private institutions on behalf of Islamic society as a whole could also perform Zakah administration, as long as they are able to effectively distribute the proceeds to the appropriate beneficiaries (Alfitri, 2006; Shehata, 1989). It is also notable that all zakah organizations are non-profit oriented as, rather than collecting commercial funds, they function to collect religious funds which have to be distributed to the stipulated recipients.

Kahf (2000) identifies two models of zakah management in contemporary Muslim countries, namely the compulsory model and the voluntary model. Under the former, collection and disbursement of zakah are carried out by the (Muslim) government on a mandatory basis as enforced by law. Countries adopting this system include, among others, Pakistan, Saudi Arabia and Yemen. In contrast, under the latter model individuals voluntarily pay zakah through government agencies or other legal agencies, based on self-assessment. Some of the countries implementing this system are Indonesia, Malaysia and Bangladesh. However, the fact that zakah is 
Al-Iqtishad: Jurnal Ilmu Ekonomi Syariah (Journal of Islamic Economics) Vol. 10 (1), January 2018

also managed by non-government institutions is not taken into account in the two models.

In Indonesia, 2011 marked advancement in the development of zakah administration, with the government's establishment of BAZNAS (the National Board of Zakah) as the main collector and supervisory body for all zakah institutions in the country (Zakah Act No 23/2011). As a result, Indonesia is adopting a compulsory zakah management model, albeit with practices which are not strict. Another important regulation is the Decree of the Ministry of Religious Affairs No. 333/2015, which establishes the category of 'certified private zakah institutions' (LAZ). In this study, all government-related zakah agencies (i.e. BAZNAS, BAZNAS Province, BAZNAS regency/city) are categorized as government-affiliated non-profit organizations, while certified private zakah institutions (LAZ) consist of corporate-affiliated zakah agencies and private zakah agencies, which together are categorized as non-governmental non-profit zakah organizations.

In contemporary Muslim societies, professionals have carried out management of zakah-including collection and distribution of zakah. However, despite modern management practices, collection of zakah in most of Muslim societies has been relatively poor. One possible reason behind the poor performance of zakah collection in Muslim countries is related to ineffectiveness of the collection strategies implemented by zakah institutions. According to Othman (1990), low levels of collection of zakah in Malaysia were related to ineffective communication between zakah administrators and zakah payers. Similarly, ineffective methods of zakah collections are found in India (Faridi, 1993) and Uganda (Abdu, 2009). Other studies also linked poor performance to lack of knowledge about zakah, as well as to limited types of zakah-appropriate assets based on the current fiqh interpretation (Kahf, 1989; Benthall, 1999).

In Indonesia, insofar as they relate to the aims of this study, systematic studies investigating this issue are rarely found. However, a recent study by Widarwati, Afif and Zazim (2017) suggests that the underperformance of zakah institutions in Indonesia might be related to the limited channels used to reach zakah payers, as well as to poor understanding of the behaviour of muzakki. In other words, fundraising approaches and strategies implemented by the zakah-collecting organizations are not effective in optimizing the potential for zakah in the world's largest Muslim country. Furthermore, when discussing the performance of zakah institutions in Indonesia, Wibisono (2015) notes that more effective collection of zakah has been consistently performed by non-government zakah organizations. Thus, there is an indication that the type of zakah organization also affects the effectiveness of zakah collection in Indonesia. However, he did not attempt to elaborate the reasons behind this fact. 


\section{Theoretical Aspects of Fundraising Definition and Scope of Fundraising}

Andreasen and Kotler (2008) define fundraising as the activity of identifying the main sources of funds and collecting financial resources from them. ${ }^{1}$ They further explain that current fundraising has reached a marketing-orientation point in its development, where it does not just make requests for monetary funding on behalf of beneficiaries, but rather operates through the exchange of value to also fulfil donors' needs. Thus, fundraising activities may include both collection and marketing activities. In line with this, Warwick (1999) states that fundraising is no longer as simple as providing funds for an organization, as its objectives may include the growth of the donor base, donor participation, the visibility of an organization's brand, and efficiency in terms of lower fundraising costs and price per service.

As advertising is the means of transferring information about products or service quality in private markets, fundraising expenditure plays this same role in charitable collection (Andreasen \& Kotler 2008). Many previous studies of fundraising focus on the methods used and marketing aspects of fundraising performance (Arnett, German \& Hunt, 2003; Bryson, 1988). Popular themes in fundraising include relationship-based fundraising and relationship marketing (Burnett, 2002; Weir \& Hibbert, 2000), database marketing (Balabanis, Stables \& Phillips, 1997); and customer relationship management (Widarwati et al., 2016). However, if fundraising is seen as an organization's strategy for revenue stability, there are relatively fewer studies of the determinants of fundraising strategy and its relationship with donor behaviour and resource availability.

\section{Fundraising and Organizational Forms}

Does organizational form matter? Schlesinger (1997, 1998, in Anheir, 2004) found that form does matter. Non-profit organizations behave more sensitively towards government requirements and community interests, but are less sensitive to donor's demands for them to be efficient and professional service providers. For example, non-profit organizations tend to be less responsive in providing social reporting than other organizations. Toepler and Anheier (2004) have classified different organizational entities and compared non-profits with corporations and government agencies. Member-serving non-profits (associations) and publicserving non-profits are compared across several aspects that could differentiate

\footnotetext{
1 There are several other definitions of fundraising too, but their essentials are more or less the
} same. 
Al-Iqtishad: Jurnal Ilmu Ekonomi Syariah (Journal of Islamic Economics) Vol. 10 (1), January 2018

the behaviour of these organizations. One factor that relates to fundraising is the resourcing method, in which corporations uses commercial resourcing, governments use coercive (taxation and policy) methods, member-serving associations use donative methods and public-serving non-profits use a combination of donative and commercial methods.

\section{Resource Dependence Theory and Fundraising Activities}

Why the type of organization format affects its fundraising activities could be explained largely from the viewpoint of resource dependency theory (Pfeffer \& Salancik, 1978). As the typical organizational format is created along with the establishment of the entity, resource availability will be likely to affect the organization's dependence on their revenue streams, and different types of organization usually have distinctive resources. Specifically, to understand the need for resources, one must adopt an open system perspective (Katz \& Kahn, 1966) in which acquiring and maintaining resources requires an organization to interact with the individuals and groups that control them. The degree of resource dependence is also determined by the importance and the concentration of the resource used. Managing its source of revenue will define how a non-profit organization behaves, including in terms of its fundraising strategies. According to resource dependency theory, the sustainability of a resource will affect how an organization will behave. An entity with a dominant or single funder scenario will be likely to mirror the structure and behaviour of its dominant funder over time (Schlesinger, 1998). For example, non-profits affiliated to certain corporations will have fundraising strategies similar to their parent companies. This factor could be applied in analysing the fundraising strategies implemented by other types of non-profit organizations.

\section{Types of Donor and Fundraising Activities}

There are three types of contribution sources for non-profits, namely private contributions, government funding and commercial incomes (Salamon \& Anheier, 1998). Private contributions come from individual and corporate donors, while government funding usually comes from block grants. Commercial incomes come from alternative fundraising, which utilizes for-profit products, and services, which support the non-profit's mission, while individual donors account for most private donation. Traditional fundraising revenues depend on contributions as their primary revenue streams (Carrol \& Stater, 2008). There are great variations across nonprofit organizations in terms of their ability to diversify their revenue structures, and these will affect their autonomy and sustainability (Salamon \& Anheier, 1998). 
Availability of funding resources varies, as the revenue structure of non-profits will depend on their types of donor; thus, the effort to maintain revenue structure through fundraising activities is also affected by the type of donor.

\section{Fundraising Strategies}

Pavicic (2003) discusses fundraising activity and believes it is not only part of marketing strategy but could also be implemented as a separate strategy that requires planning and implementation. Andreasen and Kotler (2008) further state that fundraising activities have gone through three orientation phases in their development, related to product, sales and marketing. Sargeant et al. (2001) have attempted to classify fundraising activities into two approaches: (i) the transactional approach, which focuses on immediate financial needs without using strategic planning to secure resources, and (ii) strategic approaches, which are built alongside an organization's vision, mission and long-term objectives, and which synchronize fundraising projects and resources to maintain sustainability. He argues that nonprofit organizations should transform their traditional/transactional fundraising into strategic fundraising methods that focus on influencing donors' choice of charity and increasing donor loyalty. Since the purpose of strategic fundraising is to enhance donor longevity using relationship management of donors, the non-profit sector will benefit from various concepts of relationship management taken from the marketing approach (Helfert et al., 2002; Bennet, 2005).

Thus, in general, there are two types of fundraising strategies, namely traditional fundraising and market-oriented fundraising. Traditional fundraising activities usually adopt passive approaches which collect funds through short-term actions such as on-site requests, pamphlets, banners, posters, letters and emails. These strategies are usually directive and short-term in nature. They rely on donative funding from external sources (Froelich, 1999) with minimum regard for maintaining regularity of income. In years when funding is below target, the non-profit organization will react by increasing its fundraising expenditure, expanding its efforts to target new donors. Some non-profits have the privilege of regular communities or authorities as donors, and for which they carry out the donors' social missions.

In contrast, fundraising strategies that take a more market-oriented approach purposely target individuals (potential and loyal donors) to establish regular charitable donations through the implementation of marketing approaches in their fundraising activities (Weinstein, 2009). The aim of strategic fundraising is to transform episodic and irregular donors into long-term regular members and donors (Gardner, 2013). It also aims to influence a donor's loyalty to an organization (Tschirhart, 2006, Helfert et al., 2002, Bennett, 2005). Organizations 
using proactive relationship marketing programmes to engage with their donors are proved to achieve more loyal donors and so are more successful in their fundraising (Bennett \& Barkensjo, 2005; Waters, 2009).

Various scholars have stated that revenue diversification through effective fundraising may decrease revenue volatility and dependence on donors (Carrol \& Stater, 2008). Research in the non-profit sector has affirmed that the implementation of a market orientation is important in winning donations and improving the general performance of non-profits (Andreasen \& Kotler, 2008; Pandelica et al., 2009; Levine \& Zahradnik, 2012; Chad, 2013; Rey García et al., 2013). Empirical research into non-profit marketing across countries also shows positive relationships between market orientation and fundraising performance (Ellis, 2006; Dolnicar \& Lazarevski, 2009; Pope et al., 2009; Levine \& Zahradnik, 2012; Rey García et al., 2013). In the Indonesian context, Kasri (2013) has stated that strategically segmenting donors based on their socio-demographic characteristics and observable motives is improving the fundraising approaches of zakah agencies.

Much research into fundraising has found that implementing marketorientation strategies has contributed to better fundraising performance (Balabanis et al., 1997; Bennett, 1998; Shoham et al., 2006; Dolnicar \& Lazarevski, 2009). Various scholars from multiple disciplines have also hypothesized approaches that can enable non-profits to avert financial-resource dependence through effective fundraising (Weinstein, 2009). From the discourses, it is generally suggested that the market-oriented approach includes (i) a collection approach, such as segmenting charity donors for fundraising purposes; establishing modes of payments, and (ii) a communication approach, such as maintaining a relationship with the donor, as well as documenting and disseminating various reports of output (Schlegelmilch \& Tynan, 1989; Rooney, 2001, in Bennett \& Sargeant, 2005).

Based on the literature reviewed above, it is argued that the fundraising strategies implemented by zakah organizations in Indonesia could be explained by resource dependence theory. In other words, their strategies are influenced by the sustainability of the resources they possess. For zakah agencies, whether they belong to the government (or units/agencies thereof), corporations or independent non-government organizations, resource availability will define their fundraising strategies. Those belonging to government agencies will be likely to have simpler fundraising approaches, due to the availability of their funding sources. Those embedded in corporations, such as Islamic banks, will be likely to adopt their parent company's marketing strategies for fundraising, even if they already benefit from obligatory donations from employees. Meanwhile, a private agency with no affiliations is more likely to have a market oriented fundraising-based strategy, due 
to its irregular revenue streams from unrelated/varied donors. These ideas will be empirically tested in this study.

\section{Method}

\section{Data}

This study is conducted using a qualitative approach to explain and analyze the fundraising strategies implemented by zakah agencies in three types of zakah organization in Indonesia, categorized as follows: government zakah organizations $(\mathrm{G})$, corporate zakah organizations $(\mathrm{C})$ and independent, private zakah organizations (P). Among the issues explored in this paper are collection approaches, methods of payment (channels used), communication approaches and issues in fundraising management.

Primary data was collected using a semi-structured interview protocol applied to key personnel in managerial positions in zakah agencies. The respondents were 21 management personnel (mostly directors and operational managers) from the six largest zakah organizations in Indonesia taken from the three categories of zakah agencies. ${ }^{2}$ The respondents were categorized based on the category of the organization they worked for. Thus, G is used for a government-affiliated zakah agency, $\mathrm{C}$ for a corporate-affiliated zakah agency and $\mathrm{P}$ for an independent private zakah agency. The data collected are analysed using Nvivo8 software.

\section{Research Methods}

The data obtained in this study are analysed using thematic analysis. This method was considered the most appropriate method for analysing the data obtained because of its ability to summarize, interpret and compare the key features (themes) from a large qualitative data set. Indeed, most researchers consider thematic analysis to be a useful research method for capturing the intricacies of meaning within a rich qualitative data, set such as the transcripts of semi-structured interviews (Boyatzis, 1998; Braun \& Clarke, 2006). Not surprisingly, this method has been used in a number of organizational studies (Bryman \& Burgess, 2002; Cassell \& Symon, 2004; Miller, Dingwall \& Murphy, 2004).

Six phases are recommended for conducting a thematic analysis (see Table 1). While all phases are equally important, coding is seen as the primary process for developing themes within the raw data, through which important moments in the data are recognized and coded prior to interpretation (Braun and Clarke 2006).

\footnotetext{
${ }^{2}$ They are BAZNAZ, BAZIS DKI, BMM, YBM-BRI, DD and RZ.
} 
The interpretations used for coding can include comparing theme frequencies, identifying theme co-occurrences and graphically displaying relationships between different themes (Guest et al., 2011). In this study, in presenting the coding results under the thematic analysis, both the identity numbers of respondents (R1, R2, etc.) and the combination of the respondents' identities and the types of zakah agencies they represent (G1-1, G1-2, C1-1, etc.) are utilized. Whenever necessary, explanation of the context of a particular word mentioned in the interview is written or explained in brackets. The results are described and analyzed in the next section.

Table 1. Phases of Thematic Analysis

\begin{tabular}{|c|c|c|}
\hline No & Phase & Description of the Process \\
\hline 1 & Familiarization with data & $\begin{array}{l}\text { Transcribing the data; translating the data (if necessary); reading } \\
\text { and re-reading the data; noting down initial ideas }\end{array}$ \\
\hline 2 & Generating initial codes & $\begin{array}{l}\text { Coding interesting features of the data in a systematic way across } \\
\text { the entire data set; collating data relevant to each code }\end{array}$ \\
\hline 3 & Searching for themes & $\begin{array}{l}\text { Collating codes into potential themes; gathering all data relevant } \\
\text { to each potential theme }\end{array}$ \\
\hline 4 & Reviewing themes & $\begin{array}{l}\text { Checking that the themes work in relation to the coded extracts } \\
\text { (Level 1) and the entire data set (Level 2); generating a thematic } \\
\text { 'map' of the analysis }\end{array}$ \\
\hline 5 & $\begin{array}{l}\text { Defining and naming } \\
\text { themes }\end{array}$ & $\begin{array}{l}\text { Ongoing analysis to refine the specifics of each theme as well as } \\
\text { the overall story the analysis tells; generating clear definitions } \\
\text { and names for each theme }\end{array}$ \\
\hline 6 & Producing the report & $\begin{array}{l}\text { Selection of vivid, compelling extract examples; final analysis of } \\
\text { selected extracts relating the analysis to the research question and } \\
\text { literature; producing a scholarly report of the analysis }\end{array}$ \\
\hline
\end{tabular}

Source: Braun and Clarke (2006)

\section{Result and Discussion}

\section{Result}

Important aspects of the fundraising function, such as types of donors, fundraising programmes and approaches/methods of payments, were explored to obtain insights into the models used for collecting zakah proceeds in Indonesia. This exploration leads to a general understanding that two fundraising approaches are implemented by the zakah agencies, namely retail and partnership approaches (Table 2). These approaches are associated with the two types of zakah payers, namely individuals and institutional muzakki. The characteristics of each approach are elaborated in Tables 2 to 9 . 
Table 2. Collection Approaches

\begin{tabular}{ll}
\hline Interview Question & $\begin{array}{l}\text { How do you collect zakah? (i.e. what is the model of fundraising } \\
\text { implemented in your organizations) }\end{array}$ \\
\hline Focused Coding & $\begin{array}{l}\text { Subthemes/Remarks } \\
\text { Retail fundraising approach }\end{array}$ \\
2 & $\begin{array}{l}\text { Partnership fundraising approach } \\
\text { Concluding Theme }\end{array}$ \\
& $\begin{array}{l}\text { Zakah organizations implement different approaches to fundraising. The } \\
\text { models include the retail and partnership fundraising approach. }\end{array}$ \\
\hline
\end{tabular}

The retail approach has several distinguishing characteristics (Table 3). First, it focuses on collecting zakah from individual zakah payers including those affiliated with the organizations. In this respect, some of the respondents (G1, C1 and C2) admitted that their agencies relied on revenues from groups of individual payers, in particular, employees of their parent institutions. Indeed, it was revealed during the interviews that these donors were almost exclusively the employees of parent and/or affiliated companies. Another specific individual group mentioned was hajj pilgrims, who are required to pay zakah through the appointed government zakah agency. As for the private zakah organizations, however, the general public/individuals were their main focus of fundraising.

Table 3.Focused Coding 1 for the Collection Approach

\begin{tabular}{ll}
\hline Subtheme & Retail fundraising approach \\
\hline Interview with & Remarks \\
R1 (G1-1), R9 (C1-1), R11 (C2-1) & $\begin{array}{l}\text { Focus on segmented individual zakah payers, particularly } \\
\text { those affiliated with the organizations }\end{array}$ \\
R3 (G2-1), R14 (P1-1), R21 (P2-1) & $\begin{array}{l}\text { Focus on general individual zakah payers (general public) } \\
\text { R1 (G1-1), R7 (G2-5), R9 (C1-1), }\end{array}$ \\
Relies on regular zakah collection programs \\
R1 (G1-2), R14 (P1-1), R21 (P2-1)
\end{tabular}

In terms of their fundraising programmes, almost all agencies rely on regular zakah collection programmes through which muzakki are periodically invited to pay zakah and other Islamic charitable funds. Regular and frequent communication messages are commonly employed to attract individual donors. The Islamic charities also facilitate payments by providing numerous methods of payment. According to the interviewees, the preferred method 
of payment in Greater Jakarta is transfer through banking services. The variations in payment methods are summarized below, with an indication that the private agencies utilize almost all of the payment methods available.

Table 4. Methods of Zakah Payment in Retail Approach

\begin{tabular}{|c|c|c|c|}
\hline \multicolumn{4}{|c|}{ Methods of Zakah Payments } \\
\hline Direct Payments & Implemented by & Indirect Payments & Implemented by \\
\hline $\begin{array}{l}\text { Cash payments at service } \\
\text { counter (in zakah offices) }\end{array}$ & All organizations & $\begin{array}{l}\text { Regular direct debit payment } \\
\text { (from payroll or bank } \\
\text { deposit) }\end{array}$ & $\mathrm{G} 1, \mathrm{C} 1, \mathrm{C} 2$ \\
\hline $\begin{array}{l}\text { Cash payments through zakah } \\
\text { services counter in public places } \\
\text { (mall, offices complex, etc.) }\end{array}$ & G2, P1, P2 & $\begin{array}{l}\text { Transfer through bank (via } \\
\text { bank counter, ATM, mobile } \\
\text { banking or internet banking) }\end{array}$ & All organizations \\
\hline $\begin{array}{l}\text { Cash payment through pick- } \\
\text { up service }\end{array}$ & G2, P1 & $\begin{array}{l}\text { Transfer through point of } \\
\text { payments (via post office, etc.) }\end{array}$ & P1 \\
\hline
\end{tabular}

Source: Interviews and internal documents

Table 5 describes the primary characteristics of the partnership fundraising approach. The first feature is related to collaboration with specific institutions. Unsurprisingly, government agencies are relatively successful in making partnerships with other government and government-related institutions (including business partners of government agencies), as revealed by R1 (G1-1) and R3 (G2-1). Similarly, the corporate agencies mainly rely on partners of their parent companies. Meanwhile, corporations and communities are mainly attracted to becoming partners of non-profit agencies.

Table 5. Focused Coding 2 for the Collection Approach

\begin{tabular}{ll}
\hline $\begin{array}{l}\text { Subtheme } \\
\text { Interview with }\end{array}$ & $\begin{array}{l}\text { Partnership fundraising approach } \\
\text { Remarks }\end{array}$ \\
\hline R1 (G1-1), R3 (G2-1) & $\begin{array}{l}\text { Establishing partnership with institutional muzakki/donors, } \\
\text { particularly government and government-related institutions }\end{array}$ \\
R14 (P1-1), R21 (P2-1) & $\begin{array}{l}\text { Establishing partnership with institutional muzakki/donors, } \\
\text { particularly corporations and communities }\end{array}$ \\
R14 (P1-1), R21 (P2-1) & Often associated with special fundraising events/programs \\
\hline
\end{tabular}

Another feature related to fundraising approaches is the use of special (nonregular) fundraising events often organized under the partnership model. Examples 
of such programmes are gala dinners and charity concerts as well as numerous events under Ramadhan fundraising programmes. ${ }^{3}$ On some occasions, these special programmes are conducted together with ceremonial zakah distribution events where partner organizations or institutional muzakki attend to directly observe their zakah contributions being distributed to the (agreed) beneficiaries.

Additionally, it was disclosed that different types of zakah agencies implement different approaches to 'encourage' fundraising. The government agencies, for instance, take advantage of various government regulations obligating all government officers to pay zakah through government bodies. ${ }^{4}$ In contrast, although the parent company of the corporate agencies might have relatively the same influence to direct its employees to pay their charity through the corporate-affiliated agencies, the only employees encouraged to do so were Muslims and those volunteering to do so ${ }^{5}$. For the private agencies, however, such a 'power' rarely exists and they therefore depend heavily on public funds.

Communication is another important aspect of zakah fundraising because of its role in connecting zakah payers (muzakki) with zakah organizations (amil) and zakah beneficiaries (mustahik). Responses gathered during the interviews suggest that there are two main communication approaches practised by the agenciesindividual oriented and community oriented (see Table 6). These approaches are strongly influenced by the purpose and target (audience) of the communication.

\section{Table 6. Communication Approach}

\begin{tabular}{ll}
\hline Interview Question & $\begin{array}{l}\text { How do you communicate your programs? (i.e. what models of } \\
\text { communication are implemented in your organization?) }\end{array}$ \\
\hline Focused Coding & $\begin{array}{l}\text { Subthemes/Remarks } \\
1\end{array}$ \\
2 & $\begin{array}{l}\text { Individual-oriented communication approach } \\
\text { Community-oriented communication approach }\end{array}$ \\
Concluding Theme & $\begin{array}{l}\text { Different types of zakah organizations have implemented different } \\
\text { approaches in communication. Nevertheless, there was an indication that } \\
\text { the non-profit organizations tend to use the retail-oriented model while the } \\
\text { rest tend to utilize the community-oriented model }\end{array}$ \\
\hline
\end{tabular}

${ }^{3}$ Examples include fundraising programmes aimed to provide food for sahur and ifthar for street children, weddings on the streets etc.

${ }^{4}$ Indeed, it was revealed during the interviews that individual government officials who are not Muslims are also obligated to pay zakah through the appointed agency (G1) as mandated by the Governor's Decree.

${ }^{5}$ The confirmation should be clearly stated in a written statement addressed to the company's executive, stating whether individuals do or do not agree to pay $z a k a h$ through the corporate-affiliated zakah organizations. 
Under the individual-oriented approach, communication is often associated with fundraising activities intended to attract new payers and to maintain existing ones. This is reflected in, among other things, the content of the communication instruments, which generally inform about zakah utilization programmes to be conducted and the achievements of the agencies. ${ }^{6}$ The main targets of such communication are individual zakah payers, who are also the main contributors to organizations' revenues (Table 7).

In this respect, the communication channel primarily used is media that have wide outreach and large audiences. Examples of such media include electronic media (television and radio), print media (national newspapers and magazines) and online media (websites, online newspapers, emails, social media, etc.). Even though advertising in some of the mass media such as television and newspapers is relatively expensive, particularly if done on a frequent basis (such as on a weekly basis) or in 'prime time' (such as the holy month of Ramadhan), it is seen as the most effective medium of communication, most notably by some respondents from the non-profit zakah agencies (interviews with R2-1 and R1-4). Indeed, two of the largest zakah organizations (P1 and P2) have used national television and newspapers extensively as the organizations' main media of communication/advertising.

Table 7. Focused Coding 1 for the Models of Communication

\begin{tabular}{ll}
\hline Subtheme & Individual-oriented communication model \\
\hline Interview with & Remarks \\
R3 (G2-1), R4 (G2-2), R14 (P1-1), & $\begin{array}{l}\text { Communication is often associated with fundraising } \\
\text { activities }\end{array}$ \\
R21 (P2-1) & $\begin{array}{l}\text { Targeted at general individual zakah payers } \\
\text { R4 (G2-2), R14 (P1-1), R21 (P2-1) } \\
\text { R4 (G2-2), R14 (N1-1), R21 (P2-1) }\end{array}$ \\
$\begin{array}{l}\text { Use media of communication extensively and frequently, } \\
\text { particularly mass media, which has wider outreach and } \\
\text { audience. }\end{array}$ \\
\hline
\end{tabular}

The other communication model used is the community-oriented approach, in which communication is mainly associated with transparency and accountability practices aimed at maintaining trust and long-term supportive relationships with specific or community-based zakah payers (see Table 8). As emphasized by R10, '...

${ }^{6}$ The achievements commonly given by financial magazines and NGOs include, among others, awards for highest revenue growth and most innovative programmes. These awards are often cited by the agencies in their communication and advertising materials. 
[publication is intended] to bridge...so they [zakah payers] trust us...one of these is through the website; then we advertise our programmes in national media.... He further explained that 'to maintain the zakah payers, we send them bulletins like this every three months. We also send them SMS broadcasts as a kind of "reminder" sent every Friday...to remind them to pay zakah'. Another zakah management personnel member, R1, stated that 'We publish programme and audit results in print media... to be transparent...'. Moreover, when talking about his organization's future plans for advertisements on local television, R11 underlined that, 'actually, this [publication on local television/TV] is intended more as a programme accountability activity...'.

Table 8. Focused Coding 2 for the Communication Approach

\begin{tabular}{ll}
\hline Subtheme & Community-oriented communication approach \\
\hline Interview with & Remarks \\
R1 (G1-1), R2 (G1-2), R10 (C1-2), & $\begin{array}{l}\text { Communication is often associated with transparency and } \\
\text { donor maintenance practices. }\end{array}$ \\
R11 (C2-1), R13 (C2-3) & $\begin{array}{l}\text { Targeted to zakah payers in communities, particularly those } \\
\text { affiliated with the organizations. }\end{array}$ \\
R13 (C2-3) & $\begin{array}{l}\text { Use relatively less frequent and limited types of communication } \\
\text { media. }\end{array}$ \\
\hline
\end{tabular}

It is also notable that most agencies implementing this model use a relatively limited range of communication channels. The frequency of using such media is also lower, as suitable for reaching the specific audience (zakah payer) groups. Examples of such media are low-cost print media (brochures, bulletins, magazines, pamphlets, etc.) and low-cost online media (websites and social media such as Facebook, Twitter, Instagram, etc.). Media such as newspapers and TV, however, are only used occasionally. Overall, this type of communication was more prevalent among the corporate and government agencies servicing specific segments of zakah payers.

\section{Discussion}

The findings of the study are summarized in Table 9. From these results, what can be concluded or inferred? The main finding of the study suggests that different types of zakah institutions do indeed practise different fundraising strategies. Corporate and government zakah agencies tend to use traditional fundraising strategies, in which the collection of zakah utilizes a partnership approach and communication/marketing utilizes a community-oriented approach. In contrast, 
most of the private zakah agencies use a market-oriented fundraising strategy with a retail approach for collecting zakah and an individual approach for communication.

This finding supports the theory of resource dependence (Pfeffer \& Salancik, 1978), in that each type of zakah agency has a distinctive fundraising strategy because it has distinct donors (resources). Each type of zakah organization (government-affiliated, corporate-affiliated and private zakah agencies) has a distinct pool of donors and these donors' characteristics explain donation patterns; therefore, as zakah institutions have distinctive donor types, it is clear that the type of organization does affect the fundraising strategy used.

Table 9. Summary of Findings:

Fundraising Strategies Based on Types of Zakah Institution

\begin{tabular}{|c|c|c|c|c|c|c|}
\hline $\begin{array}{c}\text { Types of } \\
\text { Zakah } \\
\text { organization }\end{array}$ & $\begin{array}{l}\text { Fundraising } \\
\text { Strategy }\end{array}$ & $\begin{array}{l}\text { Collection } \\
\text { Approach }\end{array}$ & $\begin{array}{l}\text { Funding } \\
\text { Resources }\end{array}$ & Type of donation & $\begin{array}{l}\text { Frequency } \\
\text { of } \\
\text { Donation }\end{array}$ & $\begin{array}{c}\text { Communication } \\
\text { Approach }\end{array}$ \\
\hline \multirow[b]{2}{*}{$\begin{array}{l}\text { Government- } \\
\text { affiliated }\end{array}$} & \multirow[b]{2}{*}{ Traditional } & \multirow[b]{2}{*}{$\begin{array}{l}\text { Partnership } \\
\text { Fundraising; }\end{array}$} & Individual & $\begin{array}{l}\text { Employee based } \\
\text { donation }\end{array}$ & regular & \multirow[b]{2}{*}{$\begin{array}{l}\text { Community } \\
\text { oriented }\end{array}$} \\
\hline & & & $\begin{array}{l}\text { Affiliated } \\
\text { Institution }\end{array}$ & $\begin{array}{l}\text { CSR fund, } \\
\text { municipal/state } \\
\text { zakah fund }\end{array}$ & regular & \\
\hline \multirow{2}{*}{$\begin{array}{l}\text { Corporate- } \\
\text { affiliated }\end{array}$} & \multirow{2}{*}{ Traditional } & \multirow{2}{*}{$\begin{array}{l}\text { Partnership } \\
\text { Fundraising; }\end{array}$} & Individual & $\begin{array}{l}\text { Employee based } \\
\text { donation }\end{array}$ & regular & \multirow{2}{*}{$\begin{array}{l}\text { Community } \\
\text { oriented }\end{array}$} \\
\hline & & & $\begin{array}{l}\text { Affiliated } \\
\text { Institution }\end{array}$ & $\begin{array}{l}\text { CSR fund, corporate } \\
\text { zakah fund }\end{array}$ & regular & \\
\hline \multirow{2}{*}{ Private } & \multirow{2}{*}{$\begin{array}{l}\text { Market- } \\
\text { Oriented }\end{array}$} & \multirow{2}{*}{$\begin{array}{c}\text { Retail } \\
\text { Fundraising; }\end{array}$} & Individual & Voluntary donation & irregular & \multirow{2}{*}{$\begin{array}{l}\text { Individual } \\
\text { oriented }\end{array}$} \\
\hline & & & $\begin{array}{l}\text { Non-affiliated } \\
\text { Institution }\end{array}$ & Voluntary donation & irregular & \\
\hline
\end{tabular}

Private zakah agencies utilize market-oriented strategies primarily because they do not have specific affiliations and donors. Thus, they rely on the 'market' (the public) to raise zakah funds. On the other hand, corporate-affiliated zakah agencies utilize traditional fundraising strategies largely because their existence is often to serve the mission of their donor (the parent company) and they therefore have no incentive to diversify their revenue streams to reduce overdependence on their donor. Similar approaches and reasons apply to government-affiliated zakah agencies, although it is notable that their strategies are increasingly mimicking those of the private agencies, such as large-scale partnering with third-party marketplaces to target individual donors. This indicates their readiness to embrace a marketoriented approach. 
It is notable that fundraising strategies using a market-oriented approach include the implementation of segmenting, targeting and positioning current donors in order to map potential donors. Identifying donor segmentation is important in revealing the characteristics of each donor cluster. Another benefit of implementing marketing strategies in non-profit settings is that they enable the development of longterm relationships with the main stakeholders of the organization (Arnett et al., 2003) through the process known as relationship marketing. The implementation of social marketing in the charity sector is now widespread, although the degree of market orientation in non-profit organizations is yet to be evaluated (Vazquez et al., 2002).

To further analyze the fundraising strategy implemented by each type of zakah organization, it is necessary to scrutinize the collection and communication approach. First, with respect to the collection approaches they implement, it is found that the strategies are strongly related to funding sources, types of donations and frequency of donations. In this regard, as mentioned earlier, the study finds that most government and corporate zakah agencies follow the partnership fundraising approach, while private agencies follow the retail fundraising approach. Thus, the collection approach seems to follow donor characteristics. This implies that donor traits may provide an answer as to why zakah organizations develop different fundraising approaches. In particular, the majority of the government and corporate agencies adopt a partnership approach, in which fundraising relies on a limited pool of 'rich' partners. Government-affiliated zakah agencies have municipal and stateowned enterprises as their captive markets, while corporate zakah agencies have their stakeholders as their donor base. In contrast, private zakah agencies use the retail approach, in which multichannels and a variety of media engagements are utilized. Thus, these findings support the previous conclusion that the fundraising strategies implemented are in line with the resource dependence theory as initially proposed by Pfeffer and Salancik (1978).

In relation to the donors, it is revealed that all types of non-profit institutions have two types of donor, namely individuals/retail and institutions. Retail donors consist of (i) regular individual donors and (ii) irregular individual donors. Government-based zakah organizations will have their funding resourced from regular individual donors who are mainly their employees (civil servants), while corporate-affiliated zakah agencies will have regular individual donors composed of the employees of their parent companies. Donations from regular individual donors are most likely to be acquired through 'directive policies', such portions of employee salaries being automatically debited for zakah. This type of donor does not, therefore, require extensive fundraising efforts. This may explain why fundraising efforts in government-affiliated and corporate-affiliated agencies are less varied 
than those used by private zakah agencies. As funding sources for private zakah organizations mostly come from individual, unaffiliated donors, regular donations to private zakah agencies are most likely to be a direct result of fundraising activities encouraging individuals to pay zakah periodically.

It should be noted, however, that individual donations are unstable (Gronbjerg, 1992, 1993). To develop individual donations, non-profit organizations need staff, volunteers, personal networks and advertising campaigns, with the prospect of reaching potential donors being unknown and fluctuations in funding being likely. However, regular individual donors provide safer revenue streams than 'one-off' payers due to their higher likelihood of donating regularly. Auto-debit facilities will give zakah institutions more assurance of funding stability, as donors will probably need to agree to donate only once and they do not have to frequently re-establish their decisions about how, where and how much to donate.

In Indonesia, the practice of making zakah payments through payroll or cash management is initially a result of partnership fundraising (both in government or corporate settings). As most auto-debit facilities require bank authorization, these facilities are mostly used for employees of (Islamic) banks. In this context, governmentaffiliated zakah agencies have the greatest potential for collection, due to the large number of civil servants they employ. In 2017, several municipalities and government bodies voluntarily implemented zakah through payroll, and BAZNAS (a governmentaffiliated zakah agency) is fervently proposing that the government should adopt a $2.5 \%$ zakah deduction from employees of various government bodies and stateowned enterprises (Republika, 2017). In the future, non-profit institutions are likely to extensively cultivate this channel of payment due to its long-term nature.

The study also found that there are also two types of institutional donors, namely (i) business-related institutions and (ii) non-business-related institutions. Institutional donations are categorized differently from donations from individuals, even if the funding goes to the same zakah agency. Corporate donations are funds that are donated from a company's overall profit (net income) or revenues. When a zakah organization is linked to or part of a larger corporation, such as an Islamic bank, the zakah funding could come from the main company's share of profit. In the Islamic community, zakah payment is obligatory, and corporate donation is seen as an obligation rather than an act of benevolence. It is supposed to be an action taken by any company stating that it is an Islamic company or is serving the Muslim community.

Most of the block funding available from institutional sources is from companies' corporate social responsibility (CSR) funds. As CSR is obligatory for public companies (based on Law No 40/2007 and UU No 25/2007), every public company, 
including state-owned enterprises, has to allocate 3-6\% of its profit to CSR. This is a huge potential fund for non-profit entities (including zakah collectors) in Indonesia, as there are currently 118 state-owned enterprises in the country. In order to channel these funds, most state-owned enterprises and public companies have created their own CSR divisions or are partnered with non-profit organizations (including zakah organizations) who manage their funds. Most Islamic banks and municipalities have also established their own zakah agencies and so regular payments from CSR funds are channelled solely through their affiliated zakah agencies. Typically, funding from CSR programmes should ensure revenue stability and this potential will benefit most corporate and government-affiliated zakah agencies.

Private zakah agencies are not excluded from institutional donations, as small and medium-sized enterprises, sole proprietorship businesses, start-up companies and family-owned companies are too small to establish CSR divisions or their own zakah agencies. As a result, these types of companies will opt for channelling their zakah donations to private zakah agencies. Such agencies, with their market-oriented approaches, could target such companies and offer them long-term cooperation. Depending on leadership and company culture, it is argued that a typical company would want to make regular donations and even to facilitate automatic zakah transfers from its salary account. However, such companies should be initially in an Islamic environment in which zakah payment through formal channels is strongly encouraged. Leadership and exemplary behaviour are the dominant culture for zakah donation. Most companies also prefer their zakah donation to benefit their stakeholders (company employees and their families, orphanages in the neighbourhood of the company etc.), but are lacking in resources to manage such activities. Thus zakah agencies are needed, and so should target such companies as their potential donors. In a similar way to activities undertaken with individual donors, strategic fundraising approaches are needed to maintain donor loyalty and to attract potential donors.

Related to this, it is contended that private zakah agencies have the least stable sources of revenue in comparison with the other types. Government-based agencies have the most stable sources of revenue, as civil servants are less likely to quit their jobs than other employees, and such agencies also benefit from being appointed to receive hajj pilgrims' savings. Corporate-affiliated zakah agencies also get their revenues from salaries, but in their case these come from their own and their affiliates' workforces. In consequence, private zakah agencies are under pressure to acquire and maintain stable revenue from loyal donors.

Second, with respect to the communication approach, the study found that private zakah agencies adopt more individual-oriented communication strategies, whereas government and corporate agencies engage in more community-oriented 
communication approaches. Unlike government and corporate-based zakah agencies, private agencies cannot take advantage of obliging their employees or the general public to pay zakah, even though zakah is obligatory in Islam. Fundraising programmes such as gala dinners, charity concerts and zakah payers development visitation programmes are primarily implemented by private zakah agencies, and these programmes appear to be the main channel used for them to introduce themselves to new donors and to communicate with existing donors. There are therefore strong reasons for non-profit organizations to communicate more actively to retain long-term donors.

Moreover, their use of intense programmes of communication and donorrelationship management techniques indicates that the private agencies are one step ahead of the other agencies in using various marketing approaches to increase and stabilize revenues. Private zakah agencies are able generate bigger revenues, despite having the least access to stable revenue streams of the three types of agency. One can assume that these findings indicate that private zakah agencies have implemented more elaborate communication approaches and more effective fundraising strategies, leading to an ability to generate and retain individual zakah funding. This finding supports the contention of Froelich (1999) that more limited resources force non-profits to diversify their revenue sources through various fundraising activities.

Overall, from the findings and analysis above, this study argues that the future direction for fundraising strategy is the market-oriented approach. This strategy has been practised by private zakah agencies quite successfully, most likely because of their resource dependency issues. Becoming more market-oriented is an inevitable progression for the future, because all non-profit organizations, including zakah organizations, need to have the aim of generating revenue stability.

Furthermore, to optimize the potential of zakah funds, it is suggested that all three types of zakah agency must target regular donors, both individual and institutional, and facilitate various payment methods for the sake of donor convenience. A detailed and effective fundraising strategy is needed to facilitate the transformation of sources from irregular to regular donors, especially in voluntary situations. Government and corporate-affiliated zakah agencies could use their existing partnerships with parent companies to develop, with donors' consent, more automated, direct debit payments from monthly payrolls or bank deposits. Meanwhile, private zakah organizations should communicate more actively and effectively to retain their long-term donors. All in all, the strategies are expected to increase the effectiveness of fundraising strategies implemented by zakah institutions in Indonesia. 


\section{Conclusions}

This study aims to identify and assess differences in the fundraising strategies implemented by different types of zakah institutions in Indonesia in order to support optimization of the potential for zakah collection in the country. To achieve its objectives, the study employs a qualitative research approach. Semistructured interviews were conducted with the management of the six largest zakah organizations in Indonesia. Thematic analysis was used to analyse the data.

The main finding of the study suggests that different types of zakah institutions indeed practise different fundraising (i.e. collection and communication) strategies. Corporate and government zakah agencies tend to use traditional fundraising strategies, in which collection of zakah utilizes a partnership approach and communication/marketing utilizes a community-oriented approach. In contrast, most of the private zakah agencies use market-oriented fundraising strategies, a retail approach for collecting zakah, and an individual approach for communicating information about zakah. It is also found that market-oriented fundraising strategies have resulted in greater revenue and retail donor engagement for private zakah agencies.

Taking these findings as a whole, the study argues that the results demonstrate that the resource streams of the zakah institutions significantly influence fundraising, and that this is consistent with a resource dependence theory of fundraising. It is also contends that fundraising should be integrated in a way that results in brand awareness and the perceived accountability of zakah organizations. Ultimately, it is expected that these findings could enrich the literature on zakah and provide guidance for increasing the effectiveness of fundraising strategies implemented by zakah institutions in Indonesia.

\section{References}

Abu Bakar, N. B., \& A.R.A. Rahman. (2007). A Comparative Study of Zakah and Modern Taxation. JKAU: Islamic Economics. 20(1): 25-40.

Ahmed, H. (2004). Role of Zakah and Awqaf in Poverty Alleviation. Jeddah: Islamic Development Bank, Islamic Research and Training Institute.

Al Qardawi, Y. (2000). Fiqh Al Zakah: A Comparative Study of Zakah, Regulations and Philosophy in the Light of Quran and Sunnah. Jeddah: King Abdulaziz University.

Alfitri, B. (2005). The Law of Zakat Management and Non-governmental Zakat Collectors in Indonesia. International Journal of Not-for-Profit Law. 8 (2): 55-64. 
Andreasen, A. R. (2012). Rethinking the Relationship between social/nonprofit Marketing and Commercial Marketing. Journal of Public Policy \& Marketing. 31(1): 36-41.

Anheier, H. K. (2009). What kind of Non-profit Sector, What Kind of Society? Comparative Policy Reflections. American Behavioral Scientist. 52(7): 10821094.

Anheier, H. K., S. Toepler., \& S.W. Sokolowski. (1997). The Implications of Government Funding for Non-profit Organizations: Three Propositions. International Journal of Public Sector Management. 10(3): 190-213.

Arnett, D. B., S.D. German, \& S.D. Hunt. (2003). The Identity Salience Model of Relationship Marketing Success: The Case of Non-profit Marketing. Journal of Marketing. 67(2): 89-105.

Balabanis, G., R.E. Stables, \& H.C. Phillips. (1997). Market Orientation in the Top 200 British Charity Organizations and Its impact on Their Performance. European Journal of Marketing. 31(8): 583-603.

Bamualim, C. S., \& I. Abubakar. (2005). Revitalisasi Filantropi Islam: Studi Kasus Lembaga Zakat dan Wakaf di Indonesia (The Islamic Philantrophy Revitalitation: Case Study at Zakah and Waqf Institutions in Indonesia). Jakarta: Pusat Bahasa dan Budaya, Universitas Islam Negeri Syarif Hidayatullah Jakarta dan Ford Foundation.

Bennett, R. \& A. Sargeant. (2005). Special Section: The Nonprofit Marketing Landscape. Journal of Business Research. 58: 797-805.

Bennett, R., \& A. Barkensjo. (2005). Relationship Quality, Relationship Marketing, and Client Perceptions of the Levels of Service Quality of Charitable Organisations. International journal of service industry management. 16(1): 81-106.

Benthall, J. (1999). Financial worship: the Quranic Injunction to almsgiving. Journal of the Royal Anthropological Institute. 5 (1): 27-42.

Boyatzis, R. E. (1998). Transforming Qualitative Information: Thematic Analysis and Code Development. USA: Sage Publishing.

Brooks, A. C. (2004). Evaluating the Effectiveness of Non-profit Fundraising. Policy Studies Journal. 32(3): 363-374.

Burnett, K. (2002). Relationship Fundraising: A Donor-based Approach to The Business of Raising Money. New York: John Wiley \& Sons.

Carroll, D. A., \& K.J. Stater. (2008). Revenue Diversification in Nonprofit Organizations: Does it Lead to Financial Stability?. Journal of Public Administration Research and Theory. 19(4): 947-966. 
Chad, P., E. Kyriazis, \& J. Motion. (2013). Development of a Market Orientation Research Agenda for The Nonprofit Sector. Journal of Nonprofit \& Public Sector Marketing. 25(1): 1-27.

Dolnicar, S., \& K. Lazarevski. (2009). Marketing in Non-profit Organizations: an International Perspective. International Marketing Review. 26(3): 275-291.

Firdaus, M., I.S. Beik., T. Irawan., \& B. Juanda, B. (2012). Economic Estimation and Determinations of Zakat Potential in Indonesia. Jeddah: Islamic Research and Training Institute.

Froelich, K. A. (1999). Diversification of Revenue Strategies: Evolving Resource Dependence in Nonprofit Organizations. Nonprofit and Voluntary Sector Quarterly. 28(3): 246-268.

Helfert, G., T. Ritter, \& A. Walter. (2002). Redefining Market Orientation from a Relationship Perspective: Theoretical Considerations and Empirical Results. European Journal of Marketing. 36(9/10): 1119-1139.

Holman, M. M., \& L. Sargent. (2006). Major donor fundraising. London: Directory of Social Change.

Kahf, M. (2000). Zakah Management in Some Muslim Societies. Jeddah: Islamic Research and Training Institute, Islamic Development Bank.

Kasri, R. A. (2016). Effectiveness of Zakah Targeting in Alleviating Poverty in Indonesia. Al-Iqtishad: Jurnal Ilmu Ekonomi Syariah (Journal of Islamic Economics). 8 (2): 169-186.

Katz, D., \& R.L. Kahn. (1978). The Social Psychology of Organizations (Vol. 2). New York: Wiley and Sons.

Kingma, B. R. (1993). Portfolio Theory and Nonprofit Financial Stability. Nonprofit and Voluntary Sector Quarterly. 22(2): 105-119.

Levine, H., \& A.G. Zahradnik. (2012). Online Media, Market Orientation, and Financial Performance in Nonprofits. Journal of Nonprofit \& Public Sector Marketing. 24(1): 26-42.

Ortmann, A., \& M. Schlesinger. (1997). Trust, Repute and The Role of Non-profit Enterprise. Voluntas: International Journal of Voluntary and Nonprofit Organizations. 8(2): 97-119.

Othman, R., \& A.M. Thani. (2010). Islamic Social Reporting of Listed Companies in Malaysia. The International Business \& Economics Research Journal. 9(4). $135-144$.

Pandelica, A., I. Pandelica., \& I. Dumitru. (2009). The Development of a Methodological Framework of Market Orientation Implementation: a Value Chain Perspective. Journal of American Academy of Business. 14(2): 285-292. 
Pfeffer, J., \& G.R. Salancik. (1978). The External Control of Organizations: A Resource Dependence Perspective.. New York: Harper and Row Publishers.

Pfeffer, J., \& G.R. Salancik. (2003). The External Control of Organizations: A Resource Dependence Perspective. California: Stanford University Press.

Salamon, L. M., \& H.K. Anheier. (1997). Defining the Nonprofit Sector: A Crossnational Analysis. Manchester: Manchester University Press.

Schlegelmilch, B. B., \& A.C. Tynan. (1989). The Scope for Market Segmentation Within the Charity Market: an Empirical Analysis. Managerial and Decision Economics. 10(2): 127-134.

Schlesinger, M., \& B. Gray. (1998). A Broader Vision for Managed Care, part 1: Measuring the Benefit to Communities. Health Affairs. 17(3): 152-168.

Shehata, S. I. (1989). Limitations on the use of Zakah funds in financing the socioeconomic infrastructure of society. Management of Zakah in Modern Muslim Society, Islamic Institute of Research and Training, Jeddah, Saudi Arabia.

Suhaib, A. Q. (2009). Contribution of Zakat in the Social Development of Pakistan. Pakistan Journal of Social Sciences (PJSS). 29(2): 313-334.

Tschirhart, M. (2005). Employee volunteer programs. Emerging areas of volunteering. 1: $13-30$.

Warwick, M. (1999). Fundraising Forum: How Big a Gift Should You Ask for?. Nonprofit World. 17: 15-16.

Waters, R. D., E. Burnett., A. Lamm., \& J. Lucas. (2009). Engaging Stakeholders Through Social Networking: How Nonprofit Organizations are Using Facebook. Public Relations Review. 35(2): 102-106.

Weinstein, L., \& D. Bukovinsky. (2009). Use of The Balanced Scorecard and Performance Metrics to Achieve Operational and Strategic Alignment in Arts and Culture not-for-Profits. International Journal of Arts Management. 11 (2): $42-55$.

Weir, L., \& S. Hibbert. (1998). The Role of the Fundraising Database in Building Charity-Donor Relationships. Working Paper. Glasgow: University of Strathclyde.

Wibisono, Y. (2015). Mengelola Zakat Indonesia (Management of Indonesian Zakah). Jakarta: Prenada media Group.

Widarwati, E., N.C. Afif., \& M. Zazim. (2016). Strategic Approach for Optimizing of Zakah Institution Performance: Customer Relationship Management. AlIqtishad: Jurnal Ilmu Ekonomi Syariah (Journal of Islamic Economics). 9(1): 81-94. 